\title{
ON TWO SPECIES OF THE TREMATODE GENUS DIDYMOZOON FROM THE MACKEREL
}

\author{
By H. A. Baylis, M.A., D.Sc. \\ Department of Zoology, British Museum (Natural History)
}

(Text-figs. I-6)

Taschenberg (1879) briefly described, under the name of Didymozoon scombri, a trematode which he recorded as occurring in pairs in cysts on the inside of the gill-covers of Scomber colias at Naples. Odhner (I907) found what he believed to be the same species not uncommonly in small specimens of $S$. scombrus off the west coast of Sweden, but was unable to find it in the larger fish taken in the early summer. He gives a minute description and excellent figures of the worm. Johnstone (I9I4) has also given a good, though diagrammatic, figure of its anatomy. Odhner describes the worm as occurring most commonly in paired cysts on the upper pharyngeal bones, but also in exceptional cases in cysts on the inside of the gill-covers and on the outside of the head, close behind the eye. About half the cysts examined by him contained two worms, the rest from three to seven. Johnstone describes the cysts as being most commonly situated "on the roof of the mouth beneath the pharyngo-branchials", but also sometimes on the basi-branchials, on the external surfaces of other parts of the gill-bars, or on the internal surface of the operculum. One cyst contained as many as sixteen worms. According to Dollfus (1926), he and Monod found cysts containing one, two, three or more worms in the mucosa of the mouth, palate and gills of $S$. scombrus, and also single unencysted worms under the transparent skin behind the eye.

Thus at least two authors record the same worm as occurring both inside the mouth and on the outside of the head, behind the eye. The writer has observed specimens in both situations in mackerel ( $S$. scombrus) from the English Channel, but considers that they represent two different species. By far the commonest occurrence is to find a pair of cysts in the roof of the pharynx, at the anterior end of the pad which carries the upper pharyngeal teeth. The symmetrical position of these cysts suggests that they occupy a pair of organs normally present in the mackerel-in all probability a pair of lymphatic glands. A variable number of worms may be found in each cyst, and these vary considerably in size. They agree in all essential features with the descriptions given by Odhner and by Johnstone, and are considered to belong to the species scombri Taschenberg, I879, sensu Odhner.

In a small percentage of the mackerel examined one or more elliptical 
yellowish bodies, about 3-7 $\mathrm{mm}$. long and $\mathrm{I}-\mathrm{I} \cdot 5 \mathrm{~mm}$. wide, were observed beneath the transparent outer skin of the head, behind the eye. These, on being dissected out, were found to be cysts containing from one to four worms closely resembling Didymozoon scombri, but differing from it in a number of respects. The worms are very tightly packed in the cyst. Moreover, the cystwall is relatively tough and the worms extremely fragile, so that in preserved material it is almost impossible to extract the worms without damaging them. Further, the same cyst often contains two or more worms so enormously different in size that it is very difficult to detect the small individuals and to separate them from the large, to which, when preserved, they may be firmly adherent. These difficulties, however, can be overcome by opening the cysts in the fresh condition, when the worms are usually quite readily separated.

The following is a description of the species occurring in these "facial" cysts, which it is proposed to name

\section{Didymozoon faciale, sp.n.}

The length of the worms (after mounting in Canada balsam) varies between about $0.7 \mathrm{I}$ and $16.3 \mathrm{~mm}$. The largest individuals measure (when slightly flattened under cover-glass pressure) up to about $\mathrm{I} \cdot 4 \mathrm{~mm}$. in maximum width, the smallest only $0.08 \mathrm{~mm}$. Specimens under $3 \mathrm{~mm}$. in length are generally without eggs, and in most of them the female portions of the genital apparatus are undifferentiated. The testes, however, are generally well developed and functional. This was so even in a specimen only $\mathrm{I} \cdot \mathrm{I} \mathrm{mm}$. long (Fig. 2). While in one specimen $4.6 \mathrm{~mm}$. long even the testes could not be made out, another measuring only $3 \mathrm{~mm}$. in length already had fully-developed female organs and was producing eggs. In the smallest specimen seen, which was $0.71 \mathrm{~mm}$. long, the testes appeared to be quite undifferentiated. Fig. I. Didymozoon faciale. OutFig. I gives an idea of the variation in size which may occur among the worms in a single cyst. In some the disparity is even greater, a minute

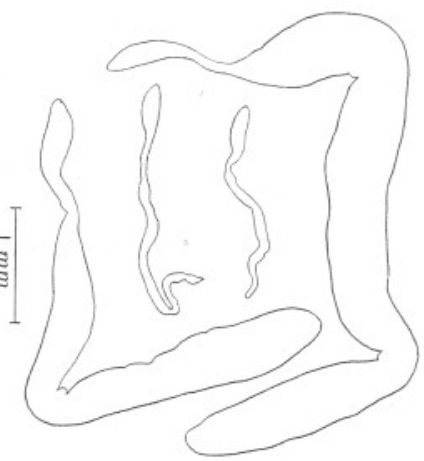
lines of the four individuals from a single cyst, drawn to the same scale, to show relative sizes. "male" worm little more than a millimetre long being found together with a fully-developed hermaphrodite individual measuring up to about $16 \mathrm{~mm}$.

The anterior portion, or "forebody", is somewhat flattened dorso-ventrally and lanceolate in outline. It is joined by a narrower "neck" to the "hindbody", which is generally cylindrical. With increasing age the "hindbody" undergoes much more rapid growth than the "forebody", so that in a large worm there is a much greater difference in their relative proportions than in small specimens. The larger individuals, owing to their close confinement 
within the cyst, are generally bent sharply upon themselves in two places, so that the anterior and posterior ends tend to overlap.

At the anterior extremity there is a small oral sucker (Figs. 2, 3, 4, 5, su). This is oval or pear-shaped, instead of being subglobular, as in D. scombri. It is also very much smaller than in that species. It measures $0.04-0.08 \mathrm{~mm}$. in length and $0.03-0.052 \mathrm{~mm}$. in maximum width, its dimensions being roughly proportional to the size of the specimen. ${ }^{\star}$ The sucker is immediately followed by a small hemispherical pharynx (Fig. 5, ph), measuring about $0.018-0.024 \mathrm{~mm}$. in diameter. $\dagger \mathrm{A}$ narrow oesophagus connects the pharynx with the intestine, which at its anterior ends forms a wide tube running transversely (Figs. 2, 4). From this two caeca (c) run posteriorly as delicate, thin-walled tubes which are thrown into numerous short dorsoventral loops, giving them a sacculated or moniliform appearance. The caeca are conspicuous only in the forebody, and, except in the youngest and smallest specimens, are difficult to detect in the hindbody, almost the whole of which is occupied by the genital apparatus. The excretory system has not been made out.

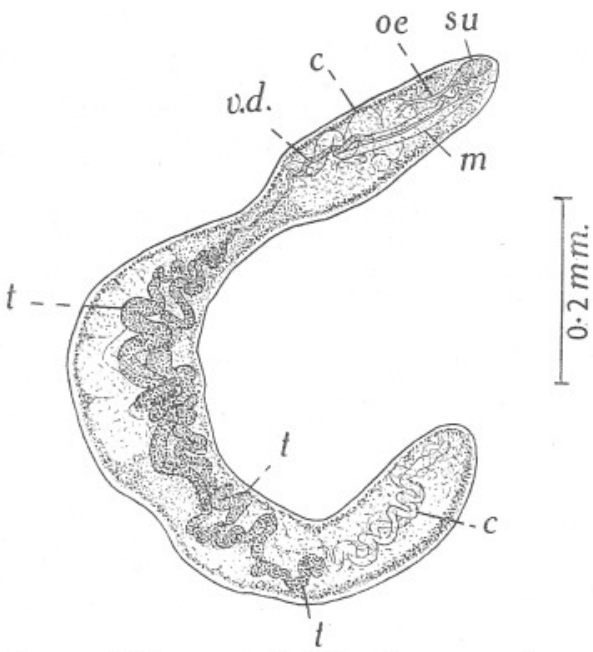

Fig. 2. Didymozoon faciale. Young specimen in which only the male organs are fully developed. $c$, intestinal caecum; $m$, metraterm; oe, oesophagus; $s u$, sucker; $t$, testes; v.d., vas deferens.

The arrangement of the genital organs is the same as in D. scombri. Ventrally to the oral sucker there is, in the medium-sized and larger specimens, a rounded muscular papilla (Figs. 3 and $4, p$ ) on which the genital pore is situated. Running almost straight back from this papilla down the middle line of the forebody is the metraterm (Figs. 2, 3, 4, m), or terminal portion of the uterus. This is apparently the first part of the female genital apparatus to be differentiated, and is visible even in such a young specimen as that shown in Fig. 2. It has, for the greater part of its length, a rather stout coat of

* In D. scombri Odhner (1907) found the diameter of the sucker to be $0.3-0.4 \mathrm{~mm}$. From the scale of magnification it appears to have been about $0.47 \mathrm{~mm}$. long and $0.53 \mathrm{~mm}$. wide in the specimen figured by Johnstone (I9I4). In specimens examined by the writer it measures $0.2 \mathrm{I}-0.6 \mathrm{~mm}$. in length and $0.25-0.55 \mathrm{~mm}$. in width. Johnstone gives the dimensions of the worms as I5-20 $\times 0.5$-0ver I mm., Odhner as $25-35 \times 1 \cdot 2-1 \cdot 75 \mathrm{~mm}$. The writer has seen much larger specimens, one of which measured $55 \mathrm{~mm}$. in length and $2 \mathrm{~mm}$. in breadth when mounted in balsam.

t In the writer's specimens of $D$. scombri the pharynx has a diameter of 0.08-0.I mm. It is difficult to detect in the larger specimens when mounted whole, as it appears to become hidden by a dense coat of cells, and also to become more intimately fused with the sucker. According to Odhner its diameter is $0.06 \mathrm{~mm}$; ; according to Johnstone's figure apparently about 0.14 $\mathrm{mm}$. 
circular muscles, but the muscles become sparser near the anterior end. Dorsally to the metraterm, and running roughly parallel to it, but with a more convoluted course, is the vas deferens (Figs. 2, 3, 4, v.d.). This also has a somewhat muscular wall, but is a much narrower and more transparent

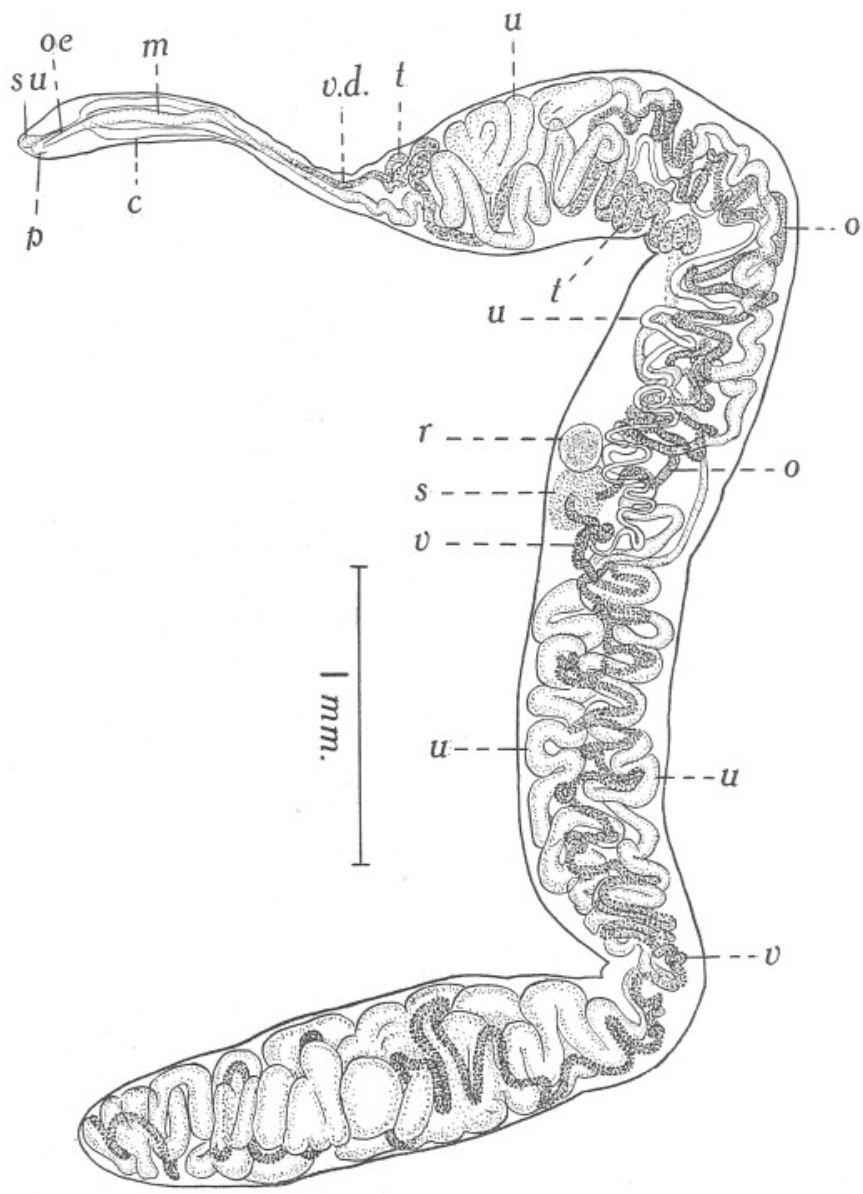

Fig. 3 Didymozoon faciale. Mature hermaphrodite individual. $c$, intestinal caecum; $m$, metraterm; $o$, ovary; oe, oesophagus; $p$, genital papilla; $r$, receptaculum seminis; $s$, shell-gland; $s u$, sucker; $t$, testis; $u$, uterus; $v$, vitelline gland; v.d., vas deferens.

tube than the metraterm. Passing through the narrow "neck" of the worm, it divides just behind it into two vasa efferentia, each of which is continuous with one of the two long, coiled, tubular testes (Figs. 2, 3, $t$ ). In young specimens (Fig. 2) these occupy the greater part of the body. In older individuals (Fig. 3), however, owing to the great growth of the hindbody, they extend only about as far as the anterior third of the total length. 
The ovary (Fig. $3, o$ ) and the vitelline gland $(v)$ are both long, convoluted, tubular organs, the former beginning some distance in front of the posterior ends of the testes, the latter close to the hinder extremity of the body. They converge towards a point a little in front of the middle of the body, where

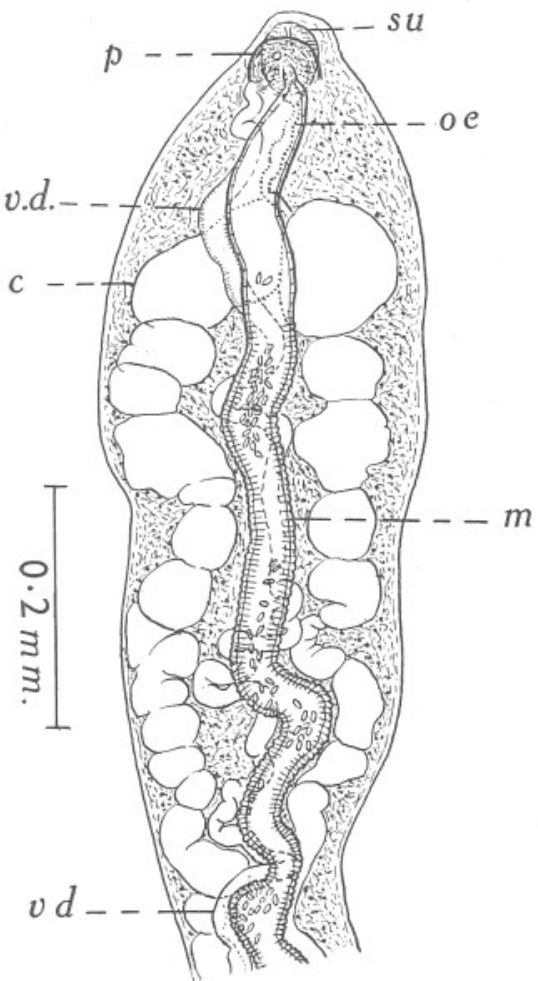

Fig. 4.

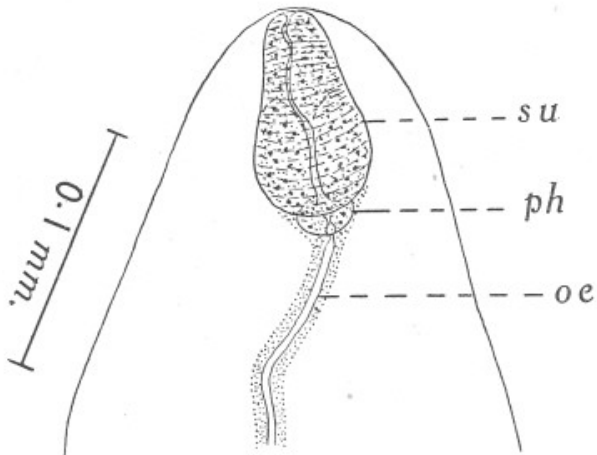

Fig. 5.

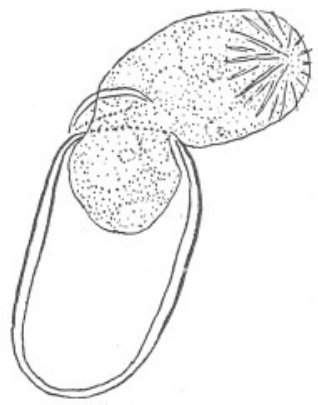

Fig. 6.

Fig. 4. Didymozoon faciale. Forebody of mature specimen; ventral view. $c$, intestinal caecum; $m$, metraterm oe, oesophagus (dotted outline); $p$, genital papilla; su, sucker; $v . d$., vas deferens.

Fig. 5. Didymozoon faciale. Anterior extremity, showing $s u$, sucker; ph, pharynx, and oe, oesophagus.

Fig. 6. Didymozoon faciale. Egg, with embryo escaping under pressure of cover-glass.

they are connected with the oviduct, with which are also connected the "shell"-gland $(s)$ and a well-developed and more or less globular receptaculum seminis $(r)$. The uterus runs forward from the shell-gland complex as a much convoluted tube almost to the anterior end of the hindbody. Here it doubles back and runs to the extreme posterior end, whence it doubles forward and pursues a much convoluted course to about the level of the shell-gland complex. From this point it appears to straighten out somewhat, and its terminal portion forms the metraterm, as already described. 
The eggs are exceedingly numerous and very small. Their shells are relatively thick and of a yellow colour, and are almost elliptical in shape. They measure about $0.018-0.02 \times 0.01 \mathrm{I} \mathrm{mm} .{ }^{\star}{ }^{\circ}$ and have an operculum at one pole. In embryos liberated from the shells by cover-glass pressure (Fig. 6), it appeared possible to confirm an observation made by Wagener (in Lieberkühn, 1854) regarding a related species found in the flying-fish, Exocoetus exsiliens. Wagener describes and figures a crown of fine spines or hooks, "wie ein Tänienhakenkranz", round the "head" of the embryo. Under high magnifications the appearance of such a crown of spines was seen in the embryos both of Didymozoon faciale and of D. scombri. Owing to their minute size it was not possible to determine the precise form of these spines, or their number, but they appeared to be of two sizes, the longer and shorter spines alternating.

\section{TAXONOMY AND NomenClature}

After a study of the literature the generic name Didymozoon Taschenberg, I879, has been provisionally adopted for the species described above. Odhner (I907) designated the species scombri as type of Didymozoon, and the genus has been accepted in this sense by Dollfus (1926) and other authors. Ishii (1935), on the other hand, refers scombri to Nematobothrium v. Beneden, I858, $\dagger$ at the same time retaining Didymozoon Taschenberg (which he unnecessarily emends to Didymozoum) as an independent genus, with $D$. sphyraenae Taschenberg as its genotype. $\neq$

According to Stiles \& Hassall (I908), Taschenberg, in erecting the genus Didymozoon, was merely renaming the genus Wedlia Cobbold, I860, and the type of both these genera is Wedlia bipartita (Wedl, 1855). This species is the first mentioned under the genus Didymozoon by Taschenberg, who renames it D. thynni. Moreover, he quotes Cobbold's reference and mentions that that author had referred this species to Wedlia. Poche (1926), however, rejects the suggestion of Stiles \& Hassall, and points out that Taschenberg neither expressly states that he is renaming Wedlia nor admits that Wedlia and Didymozoon are synonymous. It is true that Taschenberg does not definitely designate a genotype of Didymozoon, and unfortunately Cobbold (I860) also fails to make a definite designation in the case of Wedlia, though from his text it is quite evident that he regarded bipartita as the typical species.

* The eggs of D. scombri are slightly smaller, measuring 0.016-0.0175 $\times 0.01-0.0105 \mathrm{~mm}$., or, according to Odhner, $0.015 \times 0.01 \mathrm{~mm}$.

$\dagger$ Within the genus Nematobothrium Ishii proposes two new subgenera, Benedenozoum and Maclarenozoum, placing scombri in the former. Article 9 of the International Rules of Zoological Nomenclature lays down that "if a genus is divided into subgenera, the name of the typical subgenus must be the same as the name of the genus". Hence the subgenus Benedenozoum, which contains the genotype of Nematobothrium, is incorrectly named, and should be called Nematobothrium.

¥ Yamaguti (I934) also defines Nematobothrium and Didymozoon as distinct genera, and gives $D$. auxis Taschenberg as "type by elimination" of the latter. 
Didymozoon cannot, therefore, be disposed of without question as a synonym of Wedlia. *

The question whether Didymozoon (sensu Odhner) and Nematobothrium are congeneric cannot, as it seems to the writer, be determined without a fuller knowledge of the morphology of $N$. filarina $\mathrm{v}$. Beneden, the type of Nematobothrium. v. Beneden's (I858, I86I) description of this form is admittedly very incomplete, and the species does not appear to have been redescribed. v. Beneden was unable to find even an oral sucker or an intestine, whereas some of the species attributed to Nematobothrium by later authors possess not only these organs but also a ventral sucker.

Although Ishii (I935) places Nematobothrium and "Didymozoum" in distinct subfamilies, his diagnoses of these two genera are almost identical, and the distinctions between them and between the subfamilies appear to be based on extremely unsatisfactory characters. The diagnosis of Nematobothrium, however, is necessarily based mainly on species other than the genotype, while "Didymozoum", as we have seen, is quite different from the Didymozoon of Odhner.

Yamaguti's (I934) definition of Didymozoon appears to be based mainly on the characters of a new species (D. minor) described by him, and in any case his designation of $D$. auxis Taschenberg as genotype is inadmissible in view of Odhner's earlier designation of D. scombri (vide International Rules of Zoological Nomenclature, Art. 30, II, $g$ ). The same remark applies to Ishii's designation of $D$. sphyraenae.

In view of these considerations it seems best to retain Didymozoon, sensu Odhner, as distinct from Nematobothrium v. Beneden, until more conclusive evidence is brought forward to show that these genera are identical. The new species here described is unquestionably congeneric with the Didymozoon scombri of Odhner, and is therefore referred to Didymozoon.

For the material on which this paper is based the writer is greatly indebted to Mr P. G. Corbin, of the Laboratory of the Marine Biological Association, Plymouth, and to Miss Miriam Rothschild. For some excellent preparations of Didymozoon scombri thanks are due to Mr L. A. Harvey, of University College, Exeter; and for a remarkably good preparation of $D$. faciale the writer wishes to thank Mr W. J. Rees, of the Plymouth Laboratory. The specimens of both species collected by Mr Corbin and by Miss Rothschild came from mackerel landed at Plymouth and at Newlyn in November I936 and in February, March, May, October and November I937.

*Wedlia is reduced by Ishii (I935) to a subgenus of Köllikeria Cobbold, I860, the only other subgenus being named Köllikerizoum. This action again contravenes Article 9 of the International Rules, since there is no subgenus Köllikeria. The genotype of Köllikeria ( $K$. filicollis) is placed in Köllikerizoum, which name consequently must be replaced by Köllikeria. On similar grounds Ishii's subgenus Atalosparganum should be replaced by Atalostrophion MacCallum, I9I5. 


\section{REFERENCES}

Beneden, P. J. van, 1858. Mémoire sur les Vers intestinaux. Paris, viii +376 pp., 28 Pls. Also in Compt. rend. Acad. Sci., Paris, Suppl., II (I86I), pp. I-376, Pls. I-XXVII.

Coвbold, T. S., I860. Synopsis of the Distomidae. Fourn. Proc. Linn. Soc. London, Zool., v, pp. I-56.

Dollfus, R. P., I926. Sur l'État actuel de la Classification des Didymozoonidae Monticelli, I888 (=Didymozoidae Franz Poche, 1907). Ann. Parasitol., Paris, IV, pp. I48-6r.

IsHII, N., I935. Studies on the Family Didymozooidae (Monticelli, I888). Fap. Fourn. Zool., vI, pp. 279-335.

Johnstone, J., I9I4. Internal Parasites and Diseased Conditions of Fishes. Proc. E Trans. Liverpool Biol. Soc., xxviII, pp. I27-44, Pls. I-V.

LieberküHn, N., I854. Ueber die Psorospermien. Arch. f. Anat., Physiol. u. wiss. Med., Berlin, pp. I-24, Pls. I, II.

ODHNER, T., 1907. Zur Anatomie der Didymozoen: ein getrennt-geschlechtlicher Trematode mit rudimentärem Hermaphroditismus. Zoologische Studien Prof. T. Tullberg gewidmet, Uppsala, pp. 309-42, I Pl.

Poche, F., 1926. Das System der Platodaria. Arch.f. Naturg., Abt. A, xCI, pp. I-459, Pls. I-VII.

Stiles, C. W. \& Hassall, A., I908. Index-catalogue of Medical and Veterinary Zoology. Subjects: Trematoda and Trematode Diseases. U. S. Hyg. Lab. Bull., No. 37,401 pp.

TASChenberg, E. O., I879. Didymozoon, eine neue Gattung in Cysten lebender Trematoden. Zeitschr. f. Gesammt. Naturwiss., Berlin, LII ((3) IV), pp. 605-I7, P1. VI.

Yamaguti, S., I934. Studies on the Helminth Fauna of Japan. Part 2. Trematodes of Fishes, I. Fap. Fourn. Zool., v, pp. 249-54I. 